\title{
LAND CONSOLIDATION AS ONE OF THE DRIVING FORCES FOR SOCIO-ECONOMIC DEVELOPMENT OF RURAL AREAS. CASE STUDY OF THE MAŁOPOLSKA REGION
}

\author{
Małgorzata Dudzińska, Barbara Prus
}

\begin{abstract}
Summary
One of the benefits resulting from the implementation of land consolidation works should be the positive socio-economic change felt in rural areas. The aim of this paper is to examine the level of socio-economic development of rural municipalities of Małopolska Region, in which land consolidation projects were implemented in the years 2004-2013. The following were determined: the scope of implementation of land consolidation projects in municipalities of Małopolska Region, and the level of the socio-economic development of those municipalities. The study employed the following methods: analysis and synthesis of the literature, and the application of spatial-statistical approaches. The study determined that the values of the indicator expressing the dynamics of changes to the socio-economic development of municipalities were three times higher for the municipalities in which traditional land consolidation works were implemented as opposed to infrastructural ones. It was also observed that in the municipalities, in which traditional consolidation works were implemented, the level of socio-economic changes always took positive values, thus indicating the socio-economic development advantage compares to the situation in municipalities in which infrastructural consolidation projects were implemented.
\end{abstract}

\section{Keywords}

agricultural land consolidation • socio-economic level • dynamics of changes in socio-economic conditions $\bullet$ feedback

\section{Introduction}

One of the major problems in the CEE countries is land fragmentation, which varies considerably from one country to another [Thomas 2006, Pašakarnis et al. 2013, Janus et al. 2016]. In Europe, the major causes of land fragmentation have been traditionally attributed to the increase in population, laws of inheritance, and poverty [Lisec et al. 2014]. Throughout Eastern Europe, land fragmentation occurred as a side effect of the land privatization process [Hartvigsen et al. 2013].

The experience from Moldova and a number of other CEE countries shows that voluntary land consolidation instruments can be successful in addressing the structural 
problems caused by land fragmentation when integrated in a broader local rural development context [Hartvigsen et al. 2013]. It should be remembered that agricultural land consolidation is a complex procedure, covering not only the technical aspects of the design of a new governance structure itself, but also the related legal aspects [Thomas, 2006]. The implementation of land consolidation projects also requires the involvement of the residents - participants in the procedure, who frequently show a reluctant attitude towards agricultural land consolidation works [Bacior 2016, Bacior et al. 2016]. The procedure is therefore introduced in a given country, at first in the form of a pilot project, and then, at the next stage, as a systemic consolidation programme [Dudzińska and Kotlewski 2016]. Table 1 presents countries of Central and East Europe where consolidation works and pilot projects are implemented (Table 1).

Table 1. Status of the development of land consolidation programmes in Central and Eastern Europe, subdivided into three categories (as of October 2014)

\begin{tabular}{|c|l|l|l|}
\hline $\begin{array}{c}\text { Consolidation } \\
\text { status }\end{array}$ & \multicolumn{1}{|c|}{$\begin{array}{c}\text { Ongoing land } \\
\text { consolidation } \\
\text { programmes }\end{array}$} & $\begin{array}{l}\text { Introduction of land consolidation } \\
\text { projects but not yet as a systemic } \\
\text { programme }\end{array}$ & $\begin{array}{c}\text { Little or no land } \\
\text { consolidation } \\
\text { experience }\end{array}$ \\
\hline Countries & $\begin{array}{l}\text { Poland, } \\
\text { Czech Republic, } \\
\text { Slovakia, } \\
\text { Eastern part of Germany, } \\
\text { Slovenia, } \\
\text { Lithuania, Serbia. }\end{array}$ & $\begin{array}{l}\text { Estonia, Latvia, Hungary, } \\
\text { Romania, Bulgaria, Croatia, FYR } \\
\text { of Macedonia, Kosovo, Bosnia and } \\
\text { Herzegovina, Albania, Moldova, } \\
\text { Armenia, Ukraine. }\end{array}$ & $\begin{array}{l}\text { Montenegro, } \\
\text { Georgia, } \\
\text { Russian Federation, } \\
\text { Belarus. }\end{array}$ \\
\hline
\end{tabular}

Source: Authors' own study based on Hartvigsen [2015]

In Poland, two types of land consolidation projects are distinguished: traditional (structural) consolidation works, and infrastructural consolidation works. Infrastructural consolidation projects have begun only recently and, for the most part, they have been associated with the implementation of motorway or expressway construction programmes [Dobrowolski et al. 2007]. Infrastructural consolidation works differ from traditional (structural) ones. Depending of the location of the rural (agricultural) space in relation to a live investment, infrastructural consolidation projects may be implemented as part of either one or many consolidation works. Another variation is infrastructural consolidation implemented after the completion of the investment project, as long as it is necessary to transform a rural (agricultural) space, which has emerged due to the implementation of the investment project [Dobrowolski et al. 2007]. Nevertheless, infrastructural land consolidation should also meet the conditions specified for traditional (structural) consolidation projects [Dobrowolski et al. 2007]. Therefore, one of the benefits resulting from the implementation of land consolidation should be the positive socio-economic change to rural areas due to the implementation of agricultural land consolidation projects, both traditional and infrastructural. In view of the above, the aim of this paper is to examine the level of socio-economic devel- 
opment of rural municipalities of Małopolska Region, in which consolidation works were implemented. The level of socio-economic development was assessed based on a meta-indicator of the dynamics of changes, which is the difference between synthetic indicators calculated for specific municipalities for the years 2004 and 2015. The study involved 15 rural municipalities of the Małopolska Region, in which infrastructural and traditional consolidation projects were implemented. In Małopolska Region, most of the implemented consolidation projects were related to the construction of motorways (infrastructural consolidation works).

\section{Material and methods}

The study involved the analysis and synthesis of subject literature, and research based on the spatial-statistical approach. The study area covered those municipalities of Małopolska Region in which agricultural land consolidation works were implemented in the years 2004-2013 (Fig. 1).

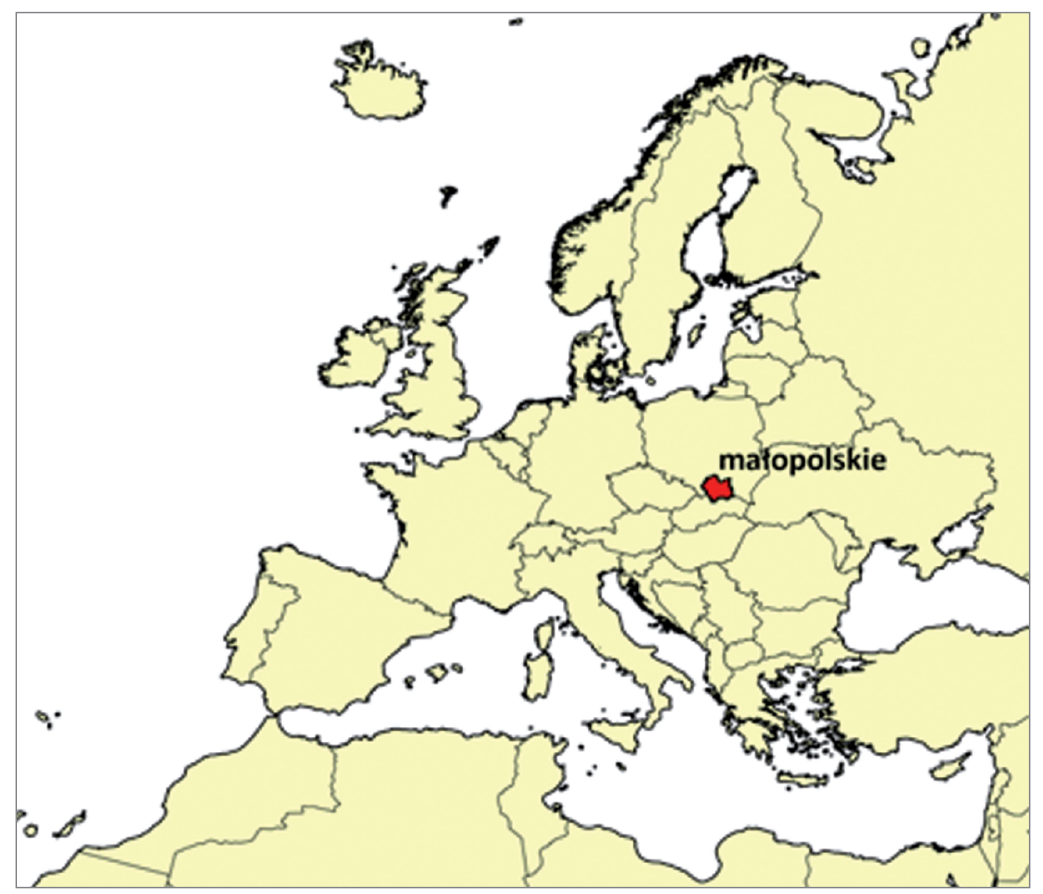

Source: Authors' own study

Fig. 1. Location of the study area in Europe

Małopolska Region is characterised by varied topography and climatic conditions. In the northern part of the region soils are markedly better, and the climate facilitates 
agricultural production, which is the reason why larger farms focused on the production of food to the market are predominant there. The more mountainous, southern part of the region comprises areas of high natural value, which are, however, characterised by unfavourable conditions for agricultural production, inter alia due to a harsher climate and unfavourable topography. Agricultural farms in this region are small in size, the land is fragmented, and local people typically look for jobs outside agriculture. In the region of Małopolska, soils of medium quality predominate, specifically, 4th soil valuation class covers $41 \%$ of the region area [Drzewiecki et al. 2014].

The first stage of the study involved the description of the implementation of consolidation measures in the municipalities of Małopolska Region. The second stage presents the dynamics of changes in terms of socio-economic conditions in the municipalities of Małopolska Region where consolidation works were implemented. The analysis was performed separately for those municipalities in which traditional consolidation projects were implemented, and for those in which infrastructural ones were implemented. The final stage involved drawing conclusions based on the conducted research.

\section{Results and discussion}

\subsection{Stage I. Implementation of land consolidation projects in the Małopolska Region}

In the years 2004-2006, traditional consolidation projects were implemented over an area of 1.2 thousand ha, while in the years 2007-2013, such consolidation projects covered an area of almost 7 thousand ha. In 11 different municipalities (Fig. 2, Table 2, Table 3), consolidation works were implemented during the construction pertaining to road and pipeline investment projects i.e. over an area of 8 thousand ha.

Table 2. Traditional consolidation objects implemented in Małopolska Region in the years 2004-2013

\begin{tabular}{|c|l|c|l|}
\hline \multicolumn{3}{|c|}{ Objects in which traditional (structural) consolidation works were implemented } \\
\hline \multicolumn{2}{|c|}{ in the years 2004-2006 } & \multicolumn{2}{c|}{ in the years 2007-2013 } \\
\hline 1 & Łętownia 1, Jordanów municipality & 1 & Ilkowice, Żabno municipality \\
\hline 2 & Marcinkowice, Radłów municipality & 2 & Łukowa, Lisia Góra municipality \\
\hline 3 & Przybysławice, Radłów municipality & 3 & Męcina wielka, Sękowa municipality \\
\hline \multirow{2}{*}{} & 4 & Barczków, Szczurowa municipality \\
\cline { 3 - 4 } & 5 & Strzelce Małe, Szczurowa municipality \\
\cline { 3 - 4 } & \multirow{2}{*}{} & 6 & $\begin{array}{l}\text { Rajsko - Szczurowa - Niedzieliska, Szczurowa } \\
\text { municipality }\end{array}$ \\
\cline { 3 - 4 } & 7 & Łętownia 2, Jordanów municipality \\
\cline { 3 - 4 } & 8 & Łętownia 3, Jordanów municipality \\
\hline
\end{tabular}




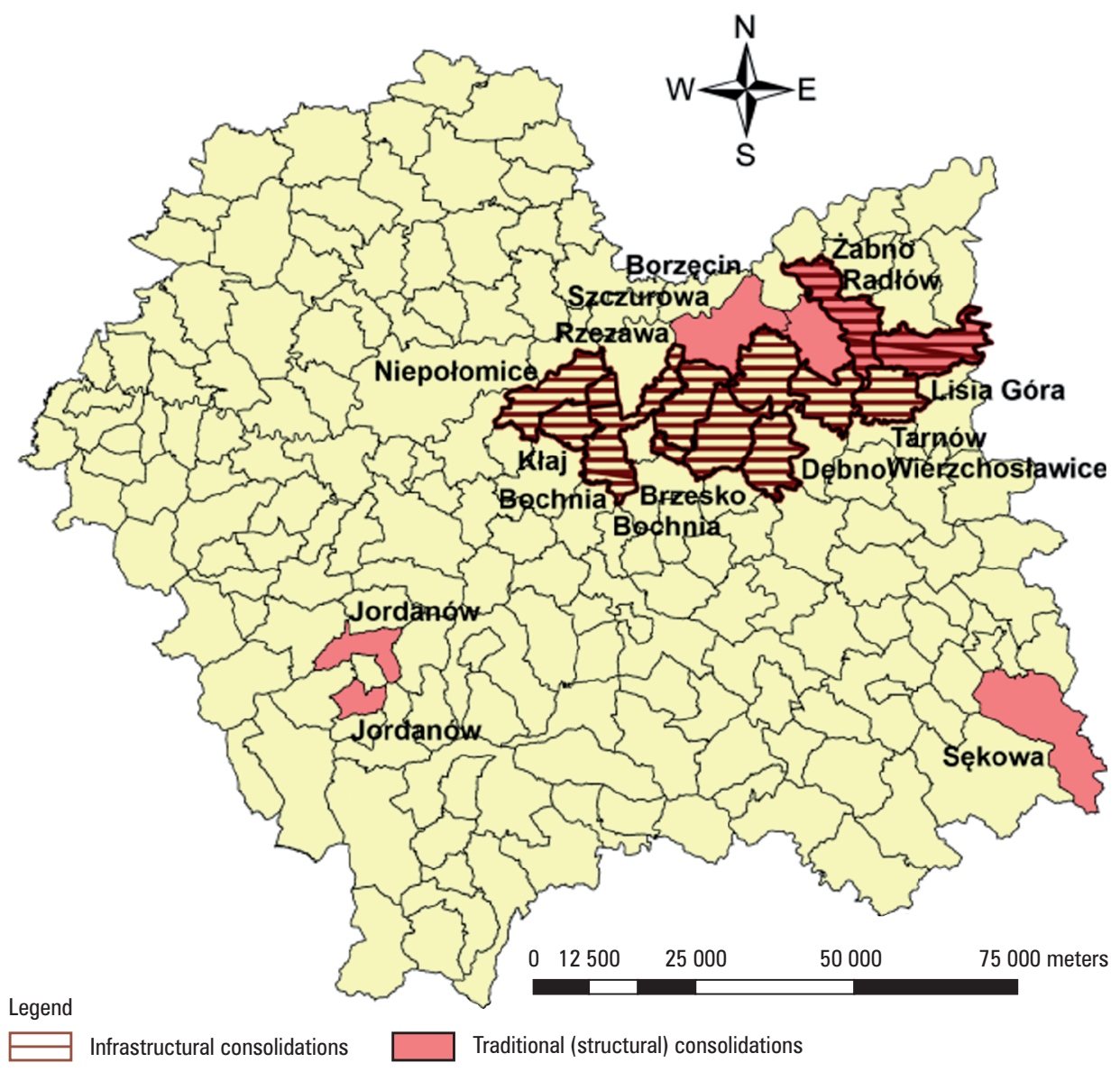

Fig. 2. Implemented consolidation projects of agricultural land in the Małopolska Region

Consolidation projects over the largest area were implemented in the municipality of Lisia Góra with an area of almost 3.3 thousand ha. Traditional (structural) consolidation works with an area of 931 ha, and infrastructural consolidation works with an area of 2360 ha were implemented there. Consolidation projects over the smallest area i.e. 194 ha were implemented in the municipality of Brzesko. In recent years, consolidation projects have been implemented in the Małopolska Region with an area of 21 thousand ha, covering only $2.26 \%$ of the arable land.

The largest percentage shares of consolidated arable land were recorded in the municipalities of Tarnów (48\%), Jordanów (46\%), and Lisia Góra (39\%). A significantly sized area i.e. $20.1-30 \%$ of arable land area under consolidation was recorded in the municipalities of Kłaj and Wierzchosławice. Between 10.1\% and 20\% of the arable land area was subjected to consolidation in the municipalities of Sękowa, Radłów, Rzezawa, Brzesko, and Szczurowa (Fig. 3). 


\begin{tabular}{|c|c|c|c|c|c|c|c|c|c|c|c|c|c|c|}
\hline Żabno & tarnowski & $\begin{array}{l}3 \\
1 \\
1\end{array}$ & 음 & $\begin{array}{l}\text { ָे } \\
\text { ઠ }\end{array}$ & $\begin{array}{l}\text { 영 } \\
\vdots\end{array}$ & $\stackrel{\infty}{-}$ & $m_{\infty}^{m}$ & $\underset{\infty}{\infty}$ & $\stackrel{H}{n}$ & 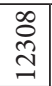 & $\underset{\sim}{\stackrel{\sim}{\sim}}$ & $\begin{array}{l}0 \\
\stackrel{2}{\circ} \\
\stackrel{2}{2}\end{array}$ & $\underset{\infty}{\stackrel{\infty}{\infty}}$ & \\
\hline Wierzchosławice & tarnowski & 3 & $\stackrel{n}{x}$ & $\underset{\Xi}{\Xi}$ & $\underset{\stackrel{\mathbb{N}}{O}}{ }$ & $\stackrel{\mathscr{P}}{ \pm}$ & 范 & 암 & $\stackrel{\varrho}{\circ}$ & 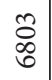 & $\begin{array}{l}\text { 오 } \\
\text { 岇 }\end{array}$ & $\begin{array}{l}\stackrel{2}{2} \\
\stackrel{1}{\circ}\end{array}$ & ঙิ & \\
\hline Tarnów & tarnowski & $\begin{array}{l}3 \\
1 \\
z\end{array}$ & $\infty$ & $\underset{⿱ ⺌}{\stackrel{\Delta}{2}}$ & $\begin{array}{l}\hat{\omega} \\
\hat{h} \\
\text { ה }\end{array}$ & के & ֶָ. & $\stackrel{\infty}{\stackrel{\infty}{0}}$ & $\stackrel{8}{-}$ & 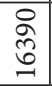 & $\underset{\stackrel{N}{N}}{\stackrel{N}{N}}$ & 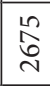 & 왐 & \\
\hline Szczurowa & brzeski & 3 & $\stackrel{\stackrel{n}{n}}{\sim}$ & $\begin{array}{l}\vec{\Delta} \\
\vec{\sim}\end{array}$ & $\begin{array}{l}\text { గి } \\
\swarrow\end{array}$ & $\mathbb{N}$ & $\begin{array}{l}\infty \\
\dot{\infty} \\
\infty\end{array}$ & $\widehat{\overbrace{}}$ & 으 & $\underset{\mathrm{\sigma}}{\tilde{\sigma}}$ & 号 & I & $\widehat{\widehat{~}}$ & \\
\hline Sękowa & gorlicki & 3 & $\stackrel{2}{2}$ & $\stackrel{\stackrel{L}{\Xi}}{\Xi}$ & 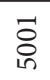 & i & $\begin{array}{l}\hat{\omega} \\
\text { in }\end{array}$ & 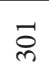 & $\stackrel{\infty}{\infty}$ & $\frac{\tilde{m}}{m}$ & 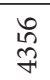 & $\vec{\infty}$ & $\underset{\mathcal{J}}{\mathcal{J}}$ & \\
\hline Rzezawa & bocheński & $\begin{array}{l}3 \\
1 \\
\Xi\end{array}$ & $\infty$ & $\underset{\exists}{\beth}$ & $\exists$ & 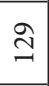 & t. & $\stackrel{m}{m}$ & $\infty$ & $\stackrel{\stackrel{N}{N}}{ }$ & $\begin{array}{l}\text { D } \\
\stackrel{\text { సे }}{ }\end{array}$ & $\begin{array}{l}\hat{\jmath} \\
\text { ڤ్ } \\
\end{array}$ & $\stackrel{\infty}{\stackrel{m}{=}}$ & \\
\hline Radłów & tarnowski & $\begin{array}{l}3 \\
1 \\
1\end{array}$ & $\infty$ & $\underset{\nexists}{\nexists}$ & 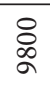 & $\underset{\exists}{\exists}$ & $\stackrel{\ddot{n}}{\ddot{n}}$ & ঐे & 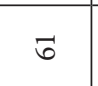 & तु & $\underset{f}{\sharp}$ & $\underset{f}{\stackrel{f}{f}}$ & 苍 & \\
\hline Niepołomice & wielicki & $\begin{array}{l}3 \\
1 \\
9\end{array}$ & ஃ & 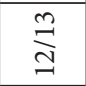 & 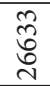 & 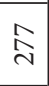 & $\underset{\infty}{\stackrel{+}{\infty}}$ & 8 & $\widehat{\approx}$ & $\begin{array}{l}\hat{\infty} \\
0 \\
0\end{array}$ & $\begin{array}{l}10 \\
\frac{1}{4}\end{array}$ & $\begin{array}{l}0 \\
\text { ț } \\
\text { t }\end{array}$ & $\stackrel{\stackrel{n}{q}}{\underset{\sim}{d}}$ & \\
\hline Lisia Góra & tarnowski & 3 & $\stackrel{2}{\varrho}$ & $\Xi$ & $\begin{array}{l}\stackrel{2}{2} \\
\stackrel{9}{J}\end{array}$ & $\underset{+}{ \pm}$ & $\stackrel{+}{\infty}$ & $\frac{1 n}{6}$ & in & $\begin{array}{l}\hat{\kappa} \\
\kappa \\
\alpha\end{array}$ & $\begin{array}{l}10 \\
\infty \\
0 \\
\text { ల }\end{array}$ & $\begin{array}{l}\stackrel{2}{\alpha} \\
\stackrel{\infty}{\sim}\end{array}$ & $\underset{\infty}{ }$ & \\
\hline Kłaj & wielicki & 3 & 20 & $\underset{a}{\vec{a}}$ & $\begin{array}{l}\hat{0} \\
\stackrel{2}{\circ} \\
\end{array}$ & $\tilde{\sigma}$ & $\stackrel{\circ}{\text { I }}$ & ڤొ & 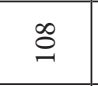 & \begin{tabular}{l}
0 \\
\multirow{0}{0}{}
\end{tabular} & $\vec{\sim}$ & 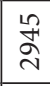 & $\vec{g}$ & \\
\hline Jordanów & suski & $\begin{array}{l}3 \\
1 \\
8\end{array}$ & สু & $\frac{0}{\ln }$ & $\vec{\Xi}$ & $\stackrel{\Xi}{=}$ & $\vec{m}$ & $\begin{array}{l}\stackrel{\circ}{n} \\
\text {. }\end{array}$ & ட & 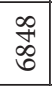 & 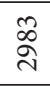 & $\begin{array}{l}0 \\
\text { } \\
\text { }\end{array}$ & 눙 & \\
\hline Dębno & brzeski & 3 & $\infty$ & $\stackrel{m}{\stackrel{m}{m}}$ & 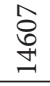 & $\stackrel{\beth}{\beth}$ & ঢே. & 令 & 2 & 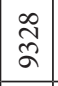 & $\underset{\text { N }}{\stackrel{+}{N}}$ & $\frac{\rho}{m}$ & $\stackrel{\infty}{\infty}$ & \\
\hline Brzesko & brzeski & $\begin{array}{l}3 \\
1 \\
9 \\
\end{array}$ & $\stackrel{0}{0}$ & $\vec{a}$ & $\begin{array}{l}\text { Ln } \\
\text { ర్ల } \\
\end{array}$ & 䓟 & 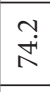 & $\begin{array}{l}\vec{\infty} \\
\infty \\
-1\end{array}$ & $\underset{\sim}{\stackrel{P}{N}}$ & 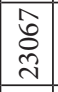 & $\begin{array}{l}\text { in } \\
\text { D } \\
\text { N }\end{array}$ & $\begin{array}{l}0 \\
\infty \\
\infty \\
\sim\end{array}$ & బิ & \\
\hline Borzęcin & brzeski & 3 & $\stackrel{\Re}{\varrho}$ & $\frac{\vec{N}}{N}$ & సે & $\infty$ & $\begin{array}{l}0 \\
\dot{0} \\
0\end{array}$ & $\vec{\infty}$ & $\hat{\sigma}$ & $\overrightarrow{\mathcal{H}}$ & $\begin{array}{l}\text { 前 } \\
\end{array}$ & $\begin{array}{l}0 \\
\text { h } \\
\text { nn }\end{array}$ & $\overrightarrow{\widehat{I}}$ & \\
\hline Bochnia & bocheński & $\begin{array}{l}\square \\
1 \\
3 \\
\end{array}$ & $\approx$ & $\underset{m}{\vec{m}}$ & $\begin{array}{l}0 \\
\text { ֵ2 } \\
2\end{array}$ & $\underset{\exists}{\stackrel{f}{+}}$ & $\begin{array}{l}\infty \\
\dot{0}\end{array}$ & $\stackrel{\infty}{\not}$ & ¿ & 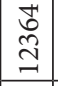 & $\begin{array}{l}\text { तै } \\
\text { ஸे }\end{array}$ & $\begin{array}{l}\text { oे } \\
\text { సे }\end{array}$ & 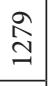 & \\
\hline 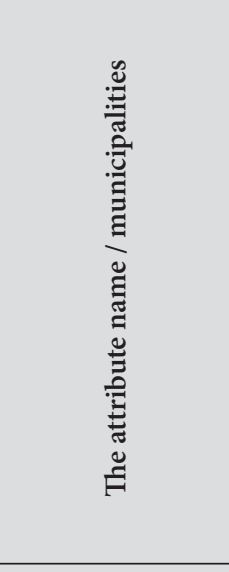 & 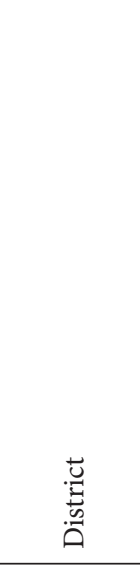 & 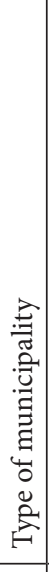 & 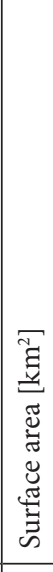 & 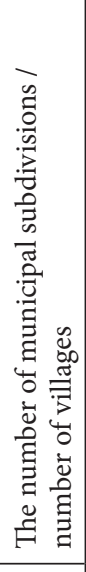 & 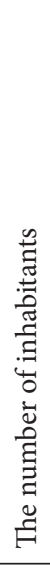 & 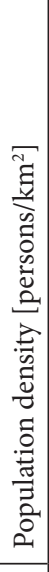 & 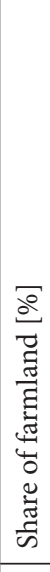 & 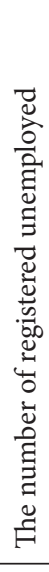 & 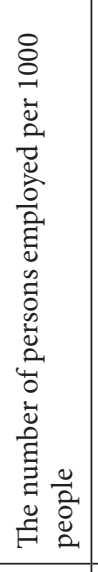 & 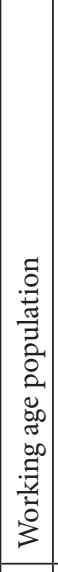 & 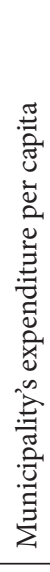 & 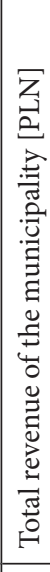 & 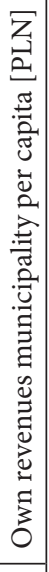 & 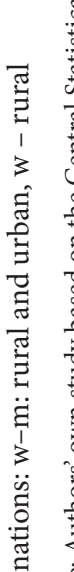 \\
\hline$\stackrel{\dot{z}}{ }$ & $\neg$ & N & $m$ & $r$ & in & 6 & 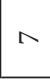 & $\infty$ & $a$ & $\stackrel{-}{-}$ & $\exists$ & $\simeq$ & $\stackrel{m}{\longrightarrow}$ & 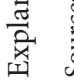 \\
\hline
\end{tabular}




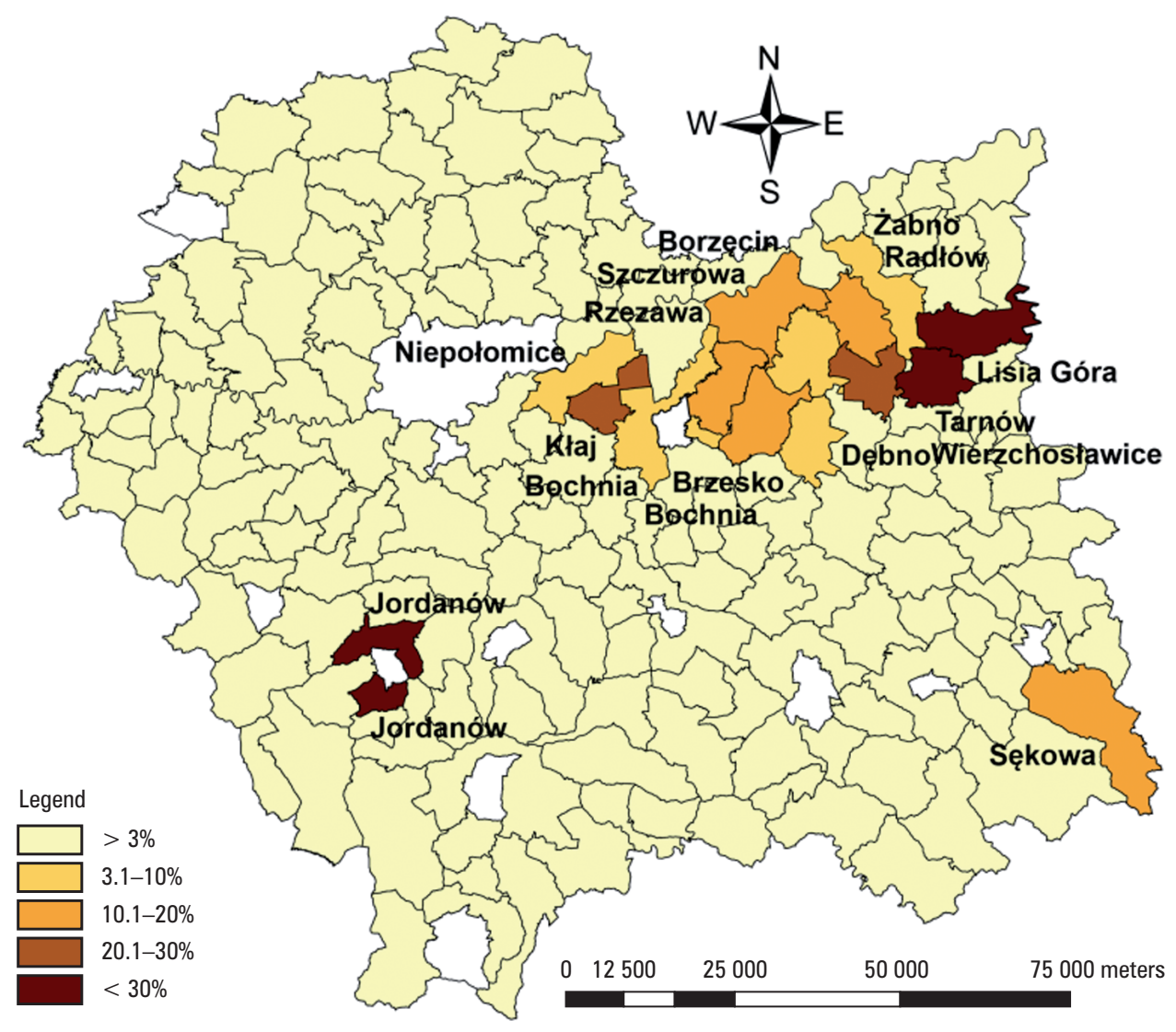

Fig. 3. Density of consolidation works per arable land area

3.2. Stage II. Presents the dynamics of changes in terms of socio-economic conditions in the municipalities of the Małopolska Region where consolidation works have been implemented

Indicators constitute valuable tools used to simplify, determine in quantitative terms, and summarize enormous flows of information, and to develop useful mechanism of feedback, which highlights spheres where the action we take is correct, and those where attention is needed. Essentially, indicators are used in order to reduce the amount of complex correlations by converting them into simple formulation, which makes assessments easier [Čiegis 2004]. In general terms, an indicator is a quantitative or a qualitative measure derived from a series of observed facts that can reveal relative positions (for instance, of a country) in a given area. When evaluated at regular intervals, an indicator can point out the direction of change across different units and through time. Therefore, indicators are quantitative information, which helps to explain how specific concerns (phenomena) change over time [Čiegis et al. 2009]. 
Each indicator has its own advantages and disadvantages; thus, it is impossible to find a single indicator for all cases. Indicators should possess the following features: simplicity, wide coverage, and possibility of qualitative assessment that allows for setting trends [Čiegis et al. 2009].

Socio-economic conditions are determined by internal (endogenous) and external (exogenous) factors. In addition to the external determinants of the given municipality's operation, the endogenous factors are those that principally provide a basis for the development of the local economy [Hryniewicz 2000, Swianiewicz and Łukomska 2004]. The issue of socio-economic development is associated with an analysis of the increase in the number of investment projects, production value, employment, the inhabitants' standard of living, as well as social and public security in the long term [Kuciński 2009]. As regards the local determinants of development, there are those resulting directly from the inhabitants' needs, and those linked to local resources. These factors can be grouped into categories of economic, social, and natural variables [Parysek 1995]. The phenomenon of socio-economic development can be described using a large number of variables describing both demographic, social, and economic conditions, and those describing the conditions of the natural environment [Grabiński et al. 1983]. In order to assess socio-economic phenomena, indicators are required that would allow one to draw conclusions concerning the ongoing processes [Nowak 1990]. The selection of indicators for quantitative analyses is determined by the accessibility of data and subjective assessments; however, it should be substantially justified.

The research basis for this study was provided by public statistical data for 15 municipalities of Małopolska Region (Table 3), made accessible as part of the Local Data Bank. 11 variables grouped into four information groups were accepted for analyses (Table 4). Additionally, for the years 2010 and 2015, variable No 12 was adopted, namely the number of operators in the category A_01 of Polish Classification of Business Activities from 2007 (agricultural cultivation, animal husbandry, hunting). The factors adopted for the study are stimulants in nature, and are indicators of the structure and intensity of phenomena.

As regards the variables describing socio-economic determinants of the municipalities, initial analyses already demonstrated that variable $x_{7}$, namely flats provided for use to the population per 1000 inhabitants, and variable $x_{8}$, namely operators in the REGON register, showed the highest variation.

Based on the data of 2015, diagnostic characteristics were selected taking into account the calculated variation coefficients and the Pearson product-moment coefficients (Table 4, Table 5). A diagnostic characteristic should be typical of a phenomenon under study, and should be demonstrating high variation; at the same time, it is recommended that it should be strongly correlated to non-diagnostic characteristics from its information group, and poorly correlated to other characteristics considered to be diagnostic ones [Kolenda 2006]. With these objectives in mind, the following variables were selected as diagnostic characteristics: $x_{1}$ - population density; $x_{6}$ - expenditures from the municipal budget per 1 inhabitant; $x_{8}$ - operators in the REGON register; 
and $x_{10}$ - percentage of population using the sewage system. Further analyses were performed on selected diagnostic characteristics.

Table 4. The initial set of variables adopted for the analysis of socio-economic conditions of the municipalities

\begin{tabular}{|c|c|}
\hline $\begin{array}{l}\text { Designation } \\
\text { of variable }\end{array}$ & Name of variable \\
\hline \multicolumn{2}{|r|}{ Demographic variables } \\
\hline$x_{1}$ & Number of population per $1 \mathrm{~km}^{2}$ (population density) \\
\hline$x_{2}$ & Number of population at non-productive age per 100 people at productive age \\
\hline$x_{3}$ & Number of persons employed per 1000 people \\
\hline$x_{4}$ & Share of the registered unemployed in the number of population at productive age [\%] \\
\hline \multicolumn{2}{|r|}{ Economic variables } \\
\hline$x_{5}$ & Total income of the municipal budget per 1 resident [PLN] \\
\hline$x_{6}$ & Total expenditures of the municipal budget per 1 resident [PLN] \\
\hline \multicolumn{2}{|r|}{ Variables from the scope of social infrastructure } \\
\hline$x_{7}$ & Flats commissioned per 1000 residents \\
\hline$x_{8}$ & Entities in the REGON register \\
\hline$x_{12}$ & $\begin{array}{l}\text { The number of operators in the category A_01 of Polish Classification of Business } \\
\text { Activities from } 2007\end{array}$ \\
\hline \multicolumn{2}{|r|}{ Variables from the scope of technical infrastructure } \\
\hline$x_{9}$ & Percentage of population using water supply system \\
\hline$x_{10}$ & Percentage of population using sewage system \\
\hline$x_{11}$ & Percentage of population using sewage system \\
\hline
\end{tabular}

Source: Authors' own study

Diagnostic characteristics were selected from among the variables adopted for the analysis. For this purpose, mutual correlations were analysed between variables adopted for the study. Normalisation of diagnostic characteristics was performed by the unitarisation method, with the application of the following formula (1):

$$
X_{i}^{\prime}=\left(\frac{X_{i}-X \min }{X \max -X \min }\right) \text { for } i=1,2, \ldots, 17
$$

where:

$X_{i}^{\prime}-$ normalised value of the $i$-th element of the characteristic $X$,

$X_{i}-$ value of the $i$-th element of the characteristic $X$ prior to normalization. 


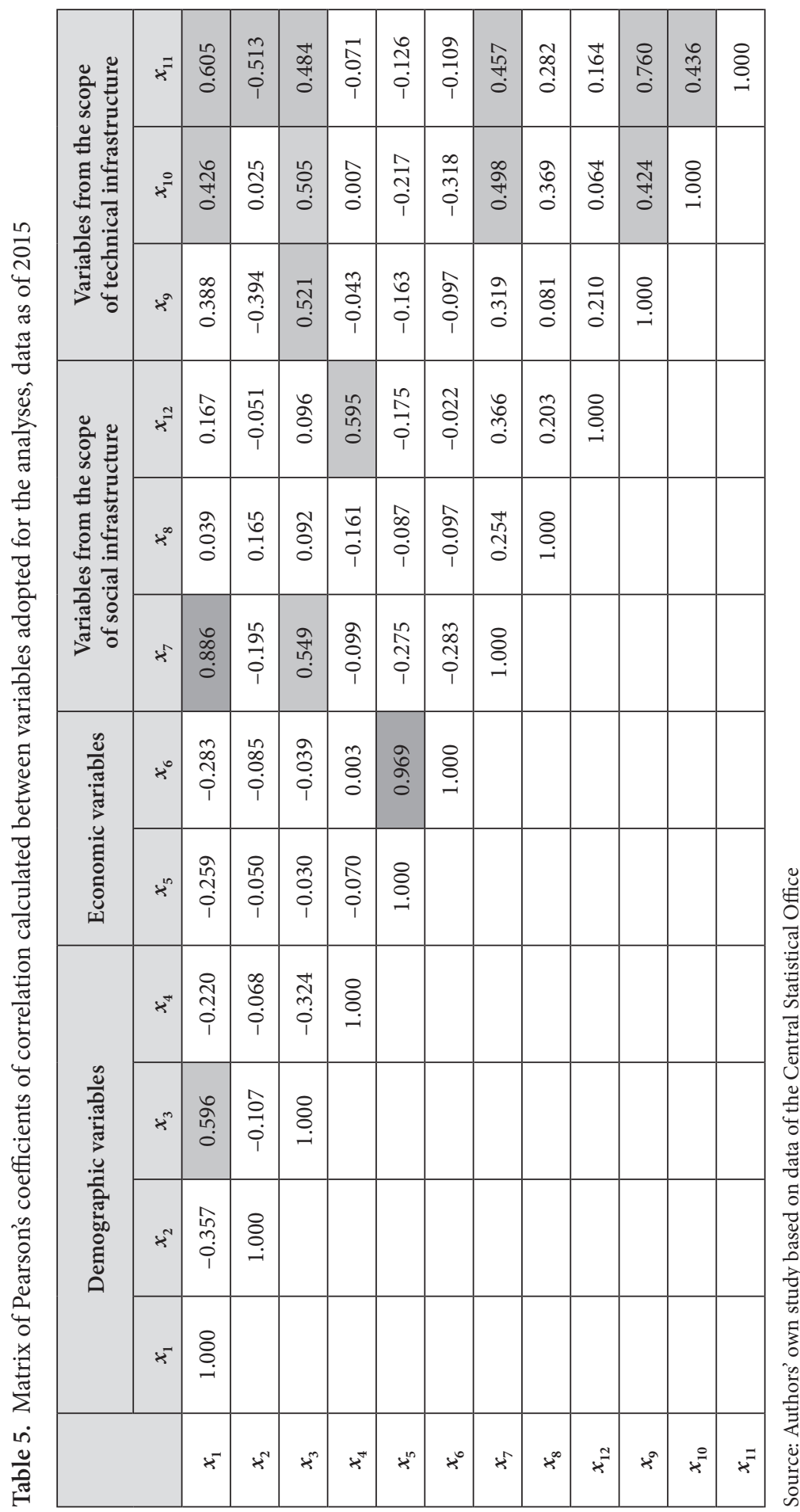


Successively, a reduction in the multi-characteristic space was performed using the method of standardised sums [Grabiński et al. 1983], and then the synthetic metaindicator presenting the arithmetic mean of the standardised diagnostic characteristics was calculated [Kolenda 2006], which is presented for the analysed municipalities in Table 5. The analysed dimensions of the development were divided into four main groups of municipalities with high, quite high, medium, and low level of development [Ziemiańczyk 2010].

A very low value of the synthetic meta-indicator in 2004 is noticeable. An average value for that year amounts to 0.37 , and corresponds to the value of the medium level. For comparison, in the years 2010 and 2015, the average value was 0.43 , which corresponds to the value of the quite high level (Table 6). A separate analysis of the group of municipalities with traditional (structural) consolidation projects revealed that the average value of the synthetic meta-indicator of the level of socio-economic determinants in 2004 amounted to 0.31 , and in 2015, it increased and amounted to 0.41 . In municipalities with infrastructural consolidation projects, the value of the meta-indicator was 0.41 and 0.44 , respectively. In order to better understand the spatial diversity of the level of socio-economic development in the analysed municipalities, a dynamic indicator of changes to the level of development was applied. The value of this indicator was determined as the difference between the level of development in the years 2004 and 2015. The indicator of the dynamics of changes in the 11 analysed municipalities took positive values, showing the growth in these municipalities (see Table 6). In 4 municipalities, the indicator of these changes took negative values. In addition, the level of the dynamics of the changes was analysed separately for the group of municipalities in which both traditional (structural) and infrastructural consolidation projects were implemented (Fig. 4 and Fig. 5).

It was noted that in 6 municipalities in which traditional consolidation projects were implemented, the dynamics of changes takes positive values, and on average it amounts to 0.10 (Fig. 4). A different situation was noted in a group of 11 municipalities in which infrastructural consolidation projects were implemented. For 4 municipalities, the indicator of the dynamics of changes in the development level takes negative values, and the average indicator of the dynamics of changes amounts to 0.03 (Fig. 5). 


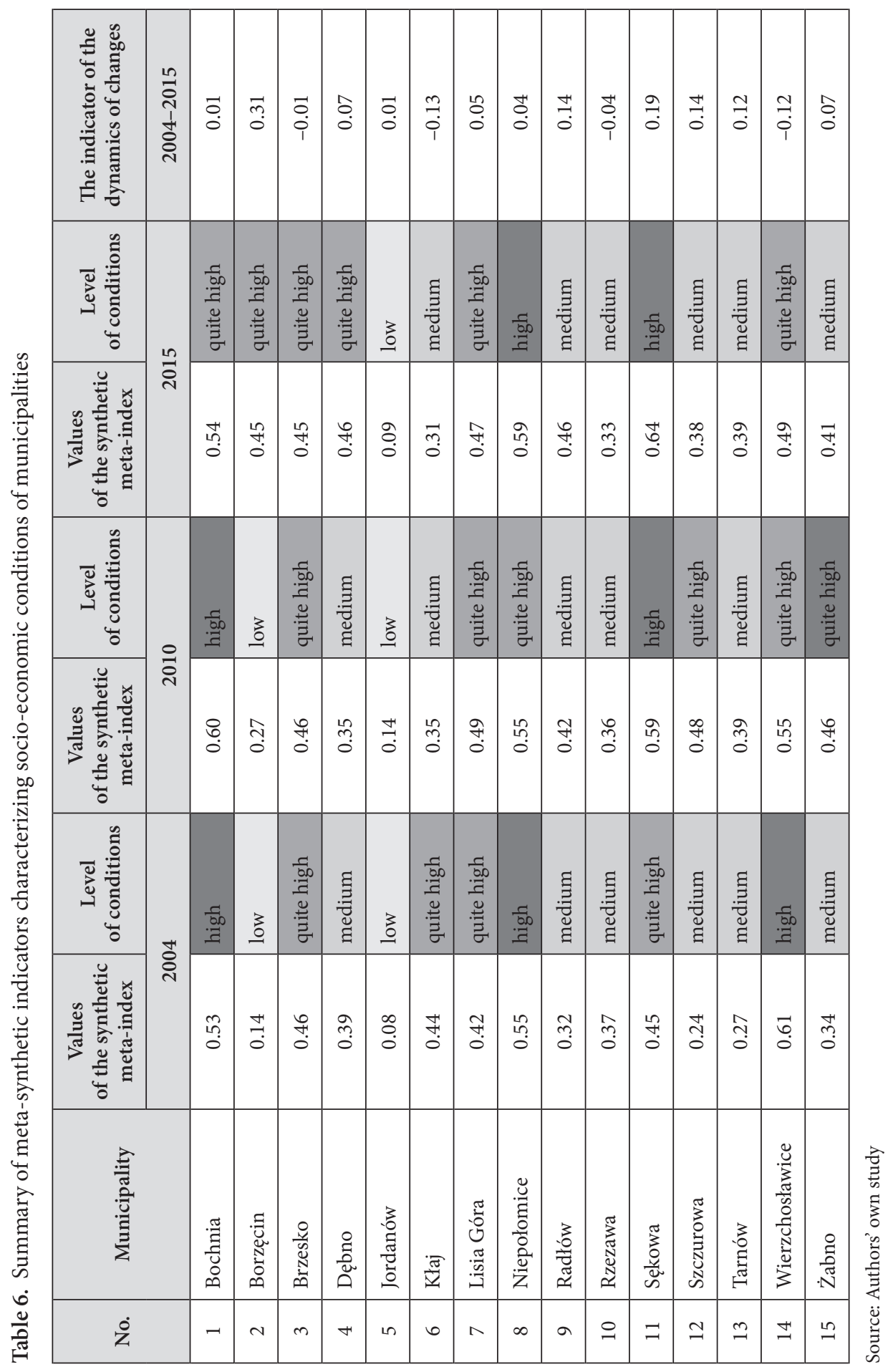




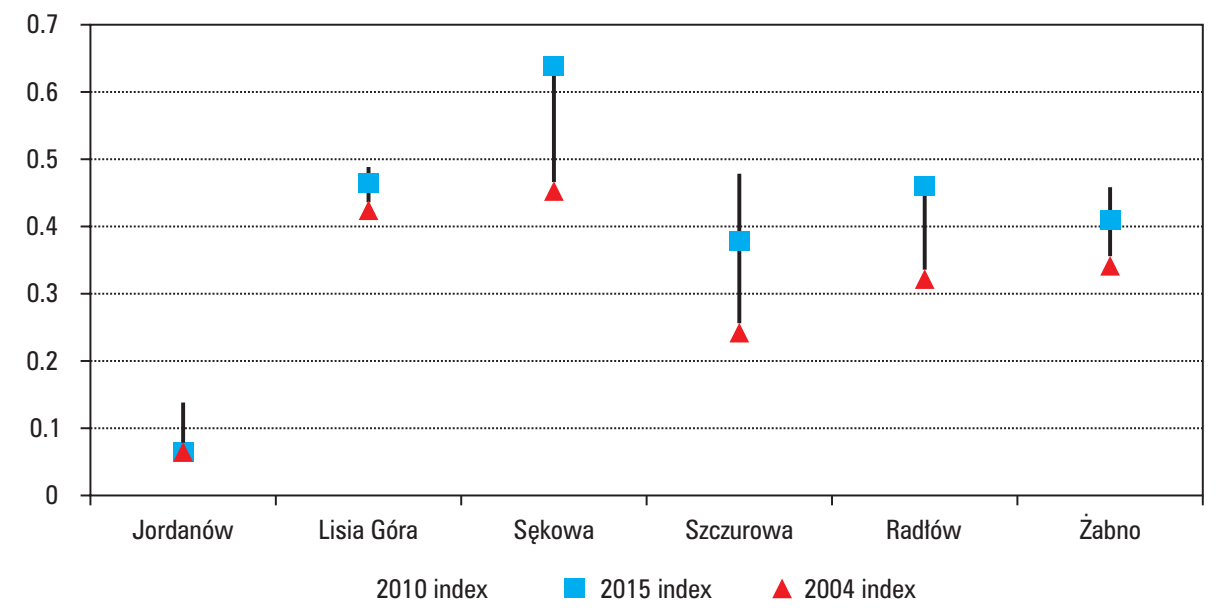

Fig. 4. The level of socio-economic development in rural municipalities of Małopolska Region, in which traditional (structural) consolidation works were implemented

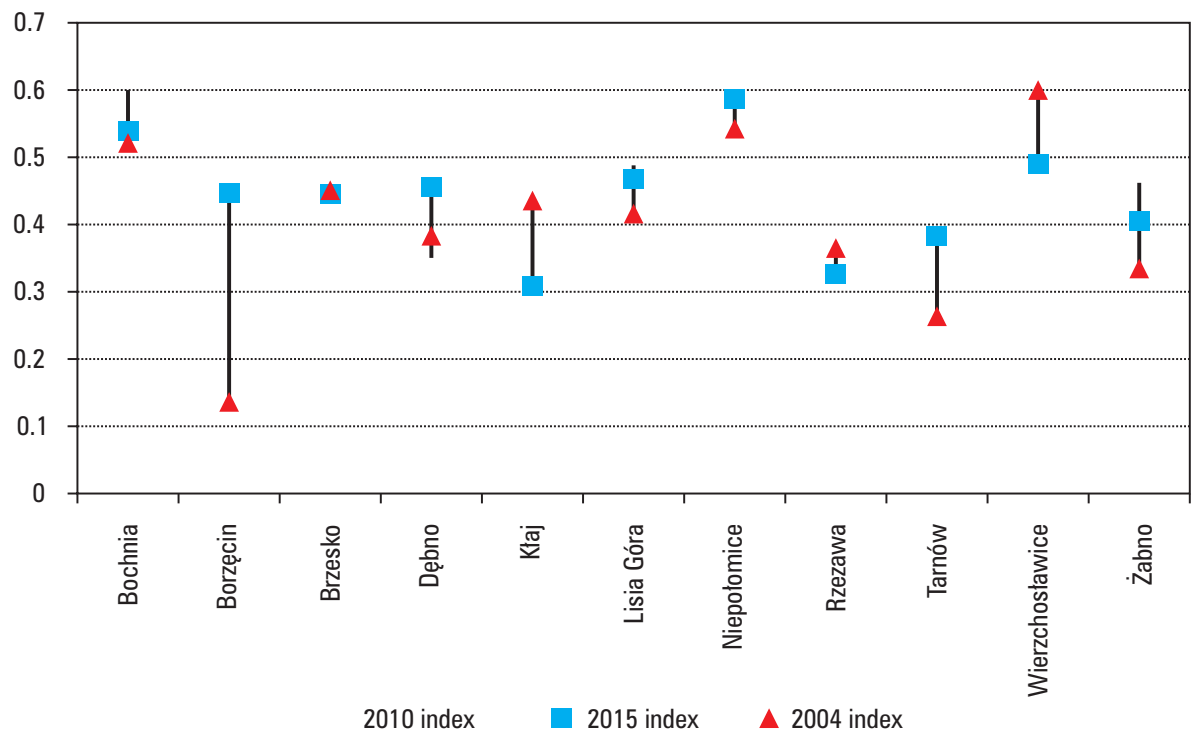

Fig. 5. The level of socio-economic development in rural municipalities of Małopolska Region, in which infrastructural consolidation works were implemented

\section{Summary and conclusions}

The implementation of both traditional (structural) and infrastructural consolidation projects of agricultural land is supposed to contribute to the development of rural areas. In this study, this development was determined based on the meta-indicator of the 
dynamics of changes to the socio-economic level. For this indicator, values being three times higher were obtained for the municipalities in which traditional consolidation works, rather than infrastructural ones, were implemented. It was also noted that in the municipalities in which traditional consolidation projects were implemented, the level of socio-economic changes always takes positive values, indicating the socio-economic growth of these municipalities, in contrast to the situation in municipalities in which infrastructural consolidation projects were implemented.

One of the reasons for such a situation may be the fact that the implementation of traditional consolidation projects is carried out in municipalities in which the consolidation participants themselves apply for the consolidation works to be performed in their area. One can believe that these farmers are aware of the benefits arising from the implementation of these investment projects, and that, through their activities, they may produce an impact on the level of development of the municipality. The situation is different for infrastructural consolidation projects, where the consolidation participants are frequently forced to take part in a particular project (ex officio consolidations), and their attitudes and expectations towards the implementation of the project are different.

In the analysis, the scope of the implementation of consolidation works must not be ignored. The works carried out in relation to the implementation of various line investment projects disorganize the existing spatial structure. These works cut through entire complexes of plots, and divide farm holdings from the land situated across the road. Within an area under motorway construction, the system of roads is changed; another problem is the relocation and modification of ditches, and the forced change to the land use designation. As a result, satisfactory outcomes of the development in the area concerned are more difficult to obtain.

\section{References}

Bacior S. 2016. Badania zmienności oddziaływania autostrady na grunty rolne na przykładzie odcinka autostrady A1. Acta Scientiarum Polonorum, ser. Formatio Circumiectus, 15, 4, 29-39.

Bacior S., Gniadek J., Piech I. 2016. The impact of highway on agricultural land on the example of a section of the A-4 highway Tarnów-Rzeszów. Infrastructure and Ecology of Rural Areas, PAN, Kraków, 411-423.

Čiegis R. 2004. Ekonomika ir aplinka: subalansuotos pletros valdymas. Kaunas, Vytauto Didžiojo universiteto leidykla.

Čiegis R., Ramanauskiene J., Startiene G. 2009. Theoretical reasoning of the use of indicators and indices for sustainable development assessment. Inzinerine Ekonomika - Engineering Economics, 33-40.

Dobrowolski K., Dziedzic W., Turek A. 2007. Scalenia gruntów w zasięgu oddziaływania autostrady A-4. Zeszyty Naukowe Akademii Rolniczej w Krakowie, ser. Geodezja, 23.

Drzewiecki W., Wężyk P., Pierzchalski M., Szafrańska B. 2014. Quantitative and Qualitative Assessment of Soil Erosion Risk in Małopolska (Poland), Supported by an Object-Based Analysis of High-Resolution Satellite Images. Pure Appl. Geophys., 171, 867-895, DOI: 10.1007/s00024-013-0669-7. 
Dudzińska M., Kotlewski L. 2016. Relations between the process of land consolidation and socio-economic conditions in municipalities in Lower Silesia. Acta Geobalcanica, 2, 1, 45-53. DOI: http://dx.doi.org/10.18509/AGB.2016.05

Grabiński T., Wydymus S., Zeliaś A. 1983. Metody prognozowania rozwoju społeczno-gospodarczego. PWE, Warszawa.

Hartvigsen M. 2015. Experiences with land consolidation and land banking in Central and Eastern Europe after 1989. Land Tenure Working Paper, 26, FAO.

Hartvigsen M., Gorgan M., Palmer D. 2013. Experiences with Land Reform and Land Consolidation in Moldova. FAO Land Tenure Journal, 22.

Hryniewicz J. 2000. Endo- i egzogeniczne czynniki rozwoju gospodarczego gmin i regionów. EIRRiL, Studia Regionalne i Lokalne, 2.

Janus J., Mika M., Leń P., Siejka M., Taszakowski J. 2016. A new approach to calculate the land fragmentation indicators taking into account the adjacent plots. Survey Review, 56, 1-7. http:// doi.dx.org/10.1080/00396265.2016.1210362

Kolenda M. 2006. Taksonomia numeryczna: klasyfikacja, porządkowanie i analiza obiektów wielocechowych. Wydawnictwo Akademii Ekonomicznej we Wrocławiu, 359.

Kuciński K. (red.). 2009. Geografia ekonomiczna, Oficyna Wolters Kluwer Polska.

Lisec A., Primozic T., Ferlan M., Sumrada R., Drobne S. 2014. Land owners' perception of land consolidation and their satisfaction with the results - Slovenian experiences. Land Use Policy, 38, 550-563, International.

Nowak E. 1990. Metody taksonomiczne w klasyfikacji obiektów społeczno-gospodarczych. Wydawnictwo PWE, Warszawa.

Parysek J. 1995. Rola samorządu terytorialnego w rozwoju lokalnym. [In:] Rozwój lokalny zagospodarowanie przestrzenne i nisze atrakcyjności gospodarczej. PAN, PWN, Warszawa.

Pašakarnis G. et al. 2013. Factors influencing land consolidation success: Lessons learned in Lithuania. [In:] Land Management. Potential, Problems and Stumbling Blocks, eds. E. Hepperle et al. Hochschulverlag, Germany.

Swianiewicz P., Łukomska J. 2004. Władze samorządowe wobec lokalnego rozwoju gospodarczego. Które polityki są skuteczne? Samorząd Terytorialny, 6.

Thomas J. 2006. Attempt on systematization of land consolidation approaches in Europe. Zeitschrift für Geod., Geoinform. und Landmanagement, Germany, 3.

Ziemiańczyk U. 2010. Ocena poziomu rozwoju społeczno-gospodarczego gmin wiejskich i wiejsko-miejskich w woj. małopolskim. Infrastruktura i Ekologia Terenów Wiejskich, 14, 31-40.

Dr hab. inż. Małgorzata Dudzińska

Uniwersytet Warmińsko-Mazurski w Olsztynie

Instytut Geografii i Gospodarki Nieruchomościami

Katedra Analiz Geoinformacyjnych i Katastru

10-720 Olsztyn, ul. Prawocheńskiego 15

e-mail: gosiadudzi@uwm.edu.pl

ORCID: 0000-0002-1140-0435

Dr hab. inż. Barbara Prus

Uniwersytet Rolniczy w Krakowie

Katedra Gospodarki Przestrzennej i Architektury Krajobrazu

30-198 Kraków, ul. Balicka 253c

e-mail: barbara.prus@urk.edu.pl

ORCID: 0000-0002-0115-7793 